\title{
STIGMA, FAMILY SUPPORT, AND THEIR ASSOCIATIONS WITH THE USE OF HIV/AIDS HEALTH SERVICES AT DR. RM. DJOELHAM HOSPITAL, MEDAN, NORTH SUMATERA
}

\author{
Ratih Sufra Rizkani, Surya Utama, Erna Mutiara \\ Universitas Sumatera Utara
}

\begin{abstract}
Backgrounds: HIV/AIDS-related stigma is a key factor that contributes to the difficulties in controlling the pandemic. Some studies showed that stigma has particular implications for both the spread and reduction of HIV/AIDS. The family is an important context that should place emphasis for eliminating HIV/AIDS-related stigma. This study aimed to determine stigma, family support, and their associations with the use of HIV/AIDS health services at DR. RM. Djoelham Hospital, Medan, North Sumatera.

Subjects and Method: This was a cross sectional study conducted at DR. RM. Djoelham Hospital, Medan, North Sumatera. A sample of 72 HIV/AIDS patients who diagnosed at least one year was selected for this study by accidental sampling. The dependent variable was the utilization of HIV/AIDS health services. The independent variables were stigma and family support. The data were collected by interview and analyzed by chi-square.

Results: The utilization of HIV/AIDS health services was associated with stigma and family support.

Conclusion: Stigma and family support are associated with the utilization of HIV/AIDS health services.
\end{abstract}

Keywords: HIV-AIDS, family support, stigma, health services

\section{Correspondence:}

Ratih Sufra Rizkani. Universitas Sumatera Utara, Medan, North Sumatera.

Email: ratih86rizkani@gmail.com. Mobile: 085261776718. 